\title{
0-149 当院における乳児の咽後膿瘍症例の検討
}

○森田浩太朗、荒井真木、加藤照幸、三澤由幾 浜松医療センター 耳鼻咽喉科

小児の深頸部膿瘍は、頸部間隙にあるリンパ節の炎症が原因といわれている。咽後膿瘍は、咽頭後リンパ節に鼻、咽頭、 中耳から感染が波及することでリンパ節炎が生じ、傍咽頭間隙に膿瘍を形成したものとされる。咽頭後リンパ節は 3 歳以降 に萎縮するため、一般的に咽後膿瘍は 3 歳未満に好発する。今回われわれは緊急手術加療を要した乳児の咽後膿瘍の 2 例を 報告する。【症例 1】2 カ月男児。いびきの増悪、喘鳴の出現で来院した。喉頭ファイバーで観察すると咽頭後壁が突出し て喉頭蓋と接していた。造影 CT 所見も併せて咽後膿瘍と診断し、同日緊急切開排膿手術を行った。術後数日は挿管管理と し、経過中に膿瘍の再貯留をみとめたため再切開をした。【症例 2】15力月女児。発熱、頸部腫脹、曣下障害を主訴に来 院。左扁桃周囲の腫脹と顎下部腫脹あり、造影 CT にて左傍咽頭間隙を中心に巨大膿瘍をみとめ、同日緊急切開排膿術を行 った。術後は数日間、経鼻エアウェイを装着し、気道経過観察をした。

\section{0-150＼cjkstart壊死性降下性縱隔炎に対する排膿術後の嚥下障害併発に関する検討}

○日高浩史、小澤大樹、平野 愛、角田梨紗子、菅野景子、恢峨井 俊、渡邊健一、香取幸夫 東北大学 医学部 耳鼻咽喉科

深頸部感染症は耳鼻咽喉科領域の感染症の中でも重篤な疾患であり、急速に膿瘍が拡大し壊死性降下性縦隔炎や敗血症な ど致死的な合併症を来すことがあるため、救命を最優先した適切な初期対応を要する。

今回、近年10年間に加療した深頸部膿瘍139例の中で、壊死性降下性縦隔炎を併発した9例の治療経過について検討した。 その中の 3 例は気管分岐部より下方への進展がないことから頸部操作のみでドレナージを行い、残りの 6 例は、胸腔鏡下の 縦隔ドレナージを併用した。

術後 1 カ月以内の死亡例は 1 例のみ（肺炎）であったが、生存例 8 例すべてに術後に曣下障害が生じた。いずれも曣下の リハビリテーションを 1 カ月以上行い、6例は経口䝮取可能となった。

降下性縦隔炎の合併例で組織の損傷が大きい場合には、術後に重度の曣下障害を来す可能性が多く、全身状態が改善した 段階でも早期に讌下機能評価とリハビリテーションの開始が重要と考えられた。

\section{0-151＼cjkstart徳島大学におけるクリニカルアナトミーラボの開設}

○阿部晃治、近藤英司、松田和徳、東 貴弘、佐藤＼cjkstart豪、北村嘉章、武田憲昭 徳島大学 医学部 耳鼻咽喉科

徳島大学では、ホルマリンで固定しない「未固定遺体」を用いた解剖の施設としてクリニカルアナトミーラボ（CAL）を 開設したので報告する。

近年、高度かつ安全な医療を求める社会的要望を背景に、手術手技や医療技術については、シミュレーターや動物等を使 用して十分なトレーニングを積むことが要求されている。しかし、複雑な人体解剖を完全に再現したトレーニング環境を構 築することは困難であった。

ホルマリンで固定されていない未固定遺体は、皮膚や皮下組織が実際の人体と同様であり、手術手技などの修練に適して いる。平成24年度に日本外科学会・日本解剖学学会が未固定遺体を用いるためのガイドラインを作成し、それを受け徳島大 学でも未固定遺体を使用するクリニカルアナトミーラボ（CAL）を開設した。ご献体をいただいた方とご家族に、生前に IC を得て、倫理審査委員会の承認の下、解剖学教室の管理下にあらかじめ教育訓練を受けた医師が、関係法令とガイドライン を遵守し実習を実施している。

\section{0-152 側頭骨疾患に対する、3D 手術シミュレーターを用いたトレーニングの有用性}

○原 陽介、山内大輔、日高浩史、村上朱里、太田 淳、渡邊健一、川瀬哲明、香取幸夫 東北大学 耳鼻咽喉・頭頸部外科

Virtual Reality 用いた耳科手術のシミュレーションは、従来は主に若手医師の解剖理解とトレーニングに使用されてき た。当院でも VOXEL-MAN Tempo システムを導入している。ドリルの振動感などをも再現し、3D 眼鏡で両眼視が可能な シミュレーターである。本システムに内蔵されたデー夕を用いたトレーニングの有効性を述べた文献は散見されるが、若手 医師が実際の症例で解剖や手技を理解するのに有用であるかは十分な検討がされていない。そこで今回演者らの施設で手術 を行った、経験を要する側頭骨疾患 4 例につき、本システムにDICOM データを取り込み、シミュレーションを行ってその 有用性の検討を行った。扱った症例は、錐体尖真珠腫、側頭下窩コレステリン肉芽腫、中頭蓋窩に進展した真珠腫、髄膜脳 瘤である。その結果、重要な構造物、瘦孔の位置、硬膜露出部位をシミュレーター上で同定することができ、術野に近い 3D 画像を得ることができた。利点と限界などをシミュレーターと手術それぞれの動画を提示しながら述べる。 


\section{0-153 当科での耳科ナビゲーション手術の試みと問題点}

○安藤奈央美 ${ }^{1)}$ 、小西将矢 ${ }^{1}$ 、馬場一泰 ${ }^{2}$ 、澤田俊輔 ${ }^{3}$ 、友田幸一 ${ }^{1)}$

関西医科大学 医学部 耳鼻咽喉科 ${ }^{12}$ 、大阪歯科大学 耳鼻咽喉科 ${ }^{2)}$ 、関西医科大学 口腔外科 ${ }^{3)}$

現在、ナビゲーションシステム (以下ナビシステム) は 9 割以上の大学病院で導入されており、耳鼻咽喉科領域、特に鼻 科領域では必要不可欠な手術支援機器となりつつある。耳科領域でも正確な解剖構造知識とともにナビシステムを用いれば 情報に基づいた安全で正確な手術が施行できるものと期待されているが、ナビシステムを積極的に使用している施設はまだ まだ限られている。その要因としては、1. 誤差 2. 顕微鏡との干渉 3 . リファレンスポイントの設定が困難、などが挙げ られる。今回、われわれは松本 (九州大学) らの考案した上顎固定型のリファレンスポイントを参考にし、口腔外科の協力 を得てマウスピース固定型光学式リファレンスアームを作成し使用した 2 例の耳科手術の経験からナビシステムの有用性お よび問題点につき検討した。また、顔面神経刺激装置を使用した際に磁場式ナビシステムが使えるかも検討したので合わせ て報告する。

\section{0-154日帰り手術クリニックにおける画像支援ナビゲーションシステムの使用経験} ○新川樹一郎、新川真那実、陶陽、大石真綾、矢野さゆり、宮本ゆう子、新川 敦 新川クリニック

当院では、日帰り手術を中心に年間1,000例以上の手術を行っている。手術の安全性を確保するために、さまざまな取り 組みを行っている。2013年は 19TB の大容量ハードディスクによる手術映像記録・配信システムである ADMENIC（カリー ナシステム株式会社）を採用した。このシステムの導入により、手術映像は院内のすべての PC から閲覧ができるようにな った。また Apple 社の FaceTime の音声伝達機能を追加し、院内手術カンファレンスができるようにした。2015年には、手 術のさらなる安全性を求め画像支援ナビゲーションシステムである Fusion ENT navigation system（メドトロニック社製） を導入した。今回はこの Fusion ENT navigation system を導入し、手術を行うことで安全性、教育面、運用面について検討 したので報告する。

\section{0-155 DICOM viewer を用いた喉頭手術の術前シミュレーション〜喉頭形成術における有用性〜}

○原 浩貴、津田潤子、堀 健志、山下裕司

山口大学大学院医学系研究科 耳鼻咽喉科学分野

DICOM は CT ・ MRI・内視鏡・超音波などの医用画像診断装置、医用画像システム、医療情報システムなどの間で医用 デジタル画像データや関連する診療データの通信、保存の国際的な標準規格であり、現在の医療における画像利用・管理に おいて中心的な役割を果たしている。この DICOM データは、DICOM viewer を用いることで、パソコン上で自由に画像を 閲覧でき、さらに関心領域を指定すれば 3 次元構築も可能である。当科においては、2008年より高機能 DICOM ビューアの 使用を開始し、耳、鼻副鼻腔、頭頸部腫瘍など各領域において術前プランニングの際にパソコン上での解析を行っている。

これまでに甲状軟骨形成術 I 型につき、開空部位を中心とした術前プランニングの実際を報告してきた。現在では、症例 により 3D プリンターを用いて喉頭枓組みモデルを自作し、術前のシミュレーションに利用し手術を行っている。われわれ が行っている術前シミュレーションを含めたプランニングの実際とその有用性につき文献的考察を加えて報告する。

\section{0-156 ヤギ頸部標本を用いた喉頭手術トレーニング}

○加藤健吾、山内大輔、原 陽介、鹿島和孝、渡邊健一、香取幸夫

東北大学 医学部 耳鼻咽喉・頭頸部外科

新規手術の手技を習得するには 1）手術書などで解剖、術式の概念、手順を学ぶ、2）手術を見学する、3）手術の助手を 行う、4）指導医の助手の元に執刀する、5）指導医なしで執刀する、6）指導医として助手を行う、という段階を経ること が一般的である。しかし実際には執刀して初めて気がつくことも多く、助手の経験と執刀の間には少なからずギャップが存 在する。今回われわれは山羊の頸部標本を用いて頸部手術（喉頭全摘、輪状咽頭筋切除、喉頭部分切除など）のトレーニン グを行った。山羊の舌骨は犬などと同様に小角相当部から茎状突起まで茎突舌骨と呼ばれる骨性構造物が伸びておりその点 ではヒトと異なるが、喉頭の構造、形状はヒトとほぼ同様であり、喉頭手術のトレーニングに非常に有用だった。山羊は人 工心臟等の実験動物として利用され、実験後ほとんどの施設で廃衰処分をしていると思われる。実験動物の有効利用という 点でも助手と執刀の間のギャップを埋めて安全な初執刀を行うという点でも、山羊の頸部標本を用いた頸部手術トレーニン グは有用と考えられた。 